Article

\title{
Artisanal Gold Mining and Mercury Contamination of Surface Water as a Wicked Socio-Environmental Problem: A Sustainability Challenge?
}

\author{
Frederick Ato Armah ${ }^{1,2 *}$ \\ ${ }^{1}$ Department of Environmental Science, School of Biological Sciences, University of Cape Coast, \\ Ghana \\ ${ }^{2}$ Department of Geography, Western University, 1151 Richmond Street, N6A 5C2, ON, Canada \\ E-Mails: farmah@ucc.edu.gh; farmah@uwo.ca (F.A.A.)
}

* Author to whom correspondence should be addressed; Tel.: +1-226-237-7311

Received: 10 August 2013 / Accepted: 31 Ocotber 2013 / Published: 01 November 2013

\begin{abstract}
In this paper, artisanal gold mining (ASM) and its associated mercury pollution of surface water in West Africa is characterized as a complex (wicked) problem in which stakeholders have conflicting interpretations of the problem and the science behind it, as well as different values, goals, and life experiences. Using fieldwork in 5 west African countries (Benin, Burkina Faso, Ghana, Mali and Senegal), the paper argues that the multiple framings of ASM as a human health, environmental, socio-economic, man-made hazard, technological, political, and policy issue by various actors and the overlap of these framings underscore the complexity and seemingly intractable nature of the problem. For that reason, policy makers, public policy professionals, and other stakeholders who tackle this ASM and mercury pollution must go beyond conventional expert and technical knowledge in order to effectively resolve it. In particular, effective solution may necessarily require holistic, not partial or linear thinking, innovative and flexible approaches, the ability to work across agency boundaries, increasing understanding and stimulating debates on the application of the accountability framework, effectively engaging stakeholders and citizens in understanding the problem and in identifying possible solutions, a better understanding of behavioral change by policy makers, and tolerating uncertainty and accepting the need for a long-term focus.
\end{abstract}




\section{Introduction}

Artisanal gold mining (ASM) is the single largest demand for mercury in the world. An estimated 1400 tonnes of mercury were used by ASM miners globally in 2011 [1]. ASM is the largest source of mercury pollution to air and water combined [1]. Today, artisanal gold is the world's second greatest source of atmospheric mercury pollution after coal combustion, according to the United Nations Environment Programme (UNEP). And with gold prices now exceeding US\$1,600 per ounce (up from less than US\$500 in the 1980s), ASM is on the rise along with its mercury problem. Mercury is a powerful neurotoxin that is harmful to people, but especially to developing fetuses, and young children [2]. It is estimated that between 10 and 15 million artisanal and small scale gold miners worldwide, including 4.5 million women and 600,000 children are exposed to the mercury amalgamation process [3]. This process transforms elemental mercury into methyl mercury, one of the most toxic organic compounds and a powerful neurotoxin that works its way up the food chain through bioaccumulation $[4,5]$.

Although ASM is a long-standing component of livelihoods in West Africa, its proliferation is both unprecedented and unparalleled especially in Benin, Burkina Faso, Ghana, Mali, and Senegal. In part, the proliferation can be attributed to the global price of gold, which is at the highest level ever, such that more people throughout these countries, have been drawn to artisanal gold mining activities. Mercury is the cheapest and easiest gold extraction method. Mercury-free gold extraction methods require more capital, training, and organization than many artisanal gold miners have access to. The deleterious effects of gold mining-induced mercury pollution in West African countries have, severally, been delineated. For instance, some human health impacts emanating from the use of mercury in gold mining have been identified in Benin [6], Burkina Faso [7], Ghana [8, 9], Mali [10] and in Senegal [3]. Yet, attempts over the last few decades to regulate ASM and its attendant mercury pollution have met with chronic policy failure. This failure epitomises existing gaps in our current understanding of the ASM-mercury pollution-human health-policy nexus; and it also reflects our limited understanding of system structure and behavior of the ASM issue; both of which are motivations for this paper. In fact, the persistence of mercury in ASM and the proliferation of its environmental and human health effects pose significant challenges to sustainability. 
From a complex systems perspective, this paper attempts to use Ghana as case study in analysing stakeholders in ASM in West Africa by categorising actors in terms of their characteristics, interests, resource use, influence and importance; elicit the fundamental nature of ASM in the selected West African countries and; explain why ASM has resisted several attempts at regulating it, and by extension, why mercury use and surface water pollution persists. In this context, ASM and its associated mercury pollution will be characterized as a wicked problem for public policymaking using the schema proposed by Rittel and Webber in their seminal paper on dilemmas in policy planning. Also, this paper will assess the manner in which some actors in ASM in West Africa have separately framed the issue. This is important because a nuanced understanding of the problem and subsequently, finding effective solutions to it are both contingent on how the issue is framed or conceptualised.

The term 'wicked' in this context is used, not in the sense of evil, but as an issue highly resistant to resolution. The terminology 'wicked' was originally proposed by [11]. In a landmark article, the authors observed that there is a whole realm of social planning problems that cannot be successfully treated with traditional linear, analytical approaches. The original focus of the wicked problem literature was on systems design at a more 'micro' level, but the concept has gradually been applied to broader social and economic policy problems. Since then, several synonymous terms for wicked problems have emerged. Most notable are the terms messes [12, 13]; social messes [14]; messy policy problems [15]; hard problems [16]; adaptive problems [17]; policy controversies [18] and illstructured problems [19].

\section{Materials and Method}

The study was conducted in Benin, Burkina Faso, Ghana, Senegal and Mali. These countries were selected as providing a fair cross-section of Sub-Saharan Africa, as well as being the site of donorassisted projects on the reduction or cessation of mercury use in gold extraction. They were also selected because of the introduction of cleaner technology alternatives to mercury. Benin is bordered to the west and east by Togo and Nigeria, respectively. Petroleum oils, refined (44\%), Gold (16\%), Cotton raw (9\%), Coconuts, Brazil nuts and cashew nuts (7\%), Copper waste and scrap (6\%) constitute the major exports of Benin. As at July 2012, Benin's population was estimated at about 9.6 million [20]. The total population in Burkina Faso was last recorded at 16.5 million in 2012 from 4.8 million in 1960, changing by 241 percent during the last 50 years [21]. 


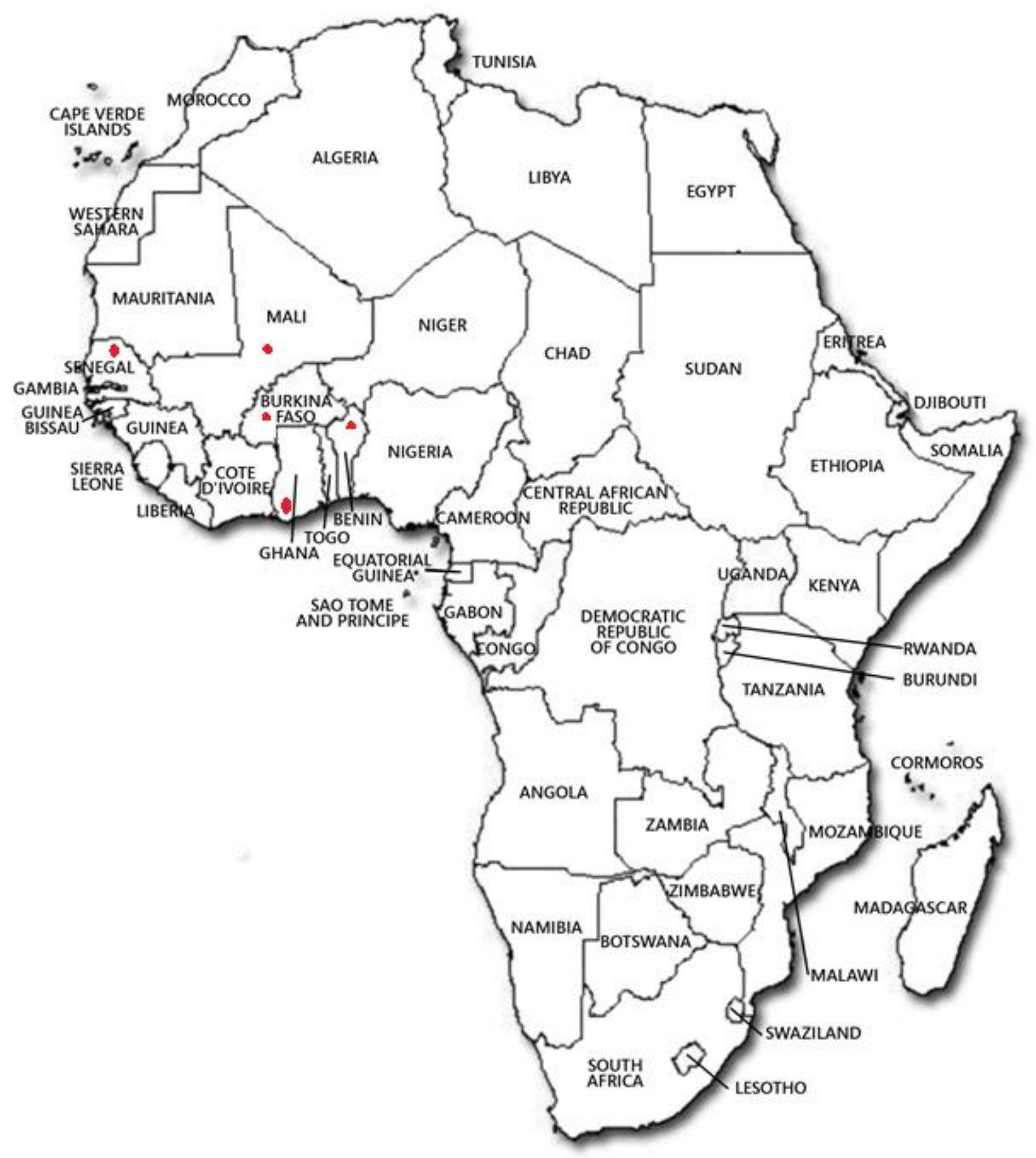

Figure 1. Map of Africa showing the study countries (highlighted in red)

The population of Burkina Faso averaged 8.86 Million from 1960 until 2012, reaching an all-time high of 16.46 Million in December of 2012. Ghana has a population of 24.3 million [22], and gold is a major export commodity, with this metal bringing in nearly 48 percent of the country's revenue. After South Africa, Ghana is the largest gold producer in Africa and in the first quarter of 2012, the country earned around $\$ 1.5$ billion through export of gold. According to the Bank of Ghana, the 
country will continue seeing an increase in revenue with gold exports. It was expected that in 2012, Ghana will earn more than $\$ 4$ billion with gold exports. The Republic of Mali is a landlocked West African country, located in the Sahel belt. More than half of Mali's territory, mainly in the north, is desert. The large majority of the around 13 million inhabitants thus live in the south of the country [23], roughly one third of them in towns. Gold mining contributed between 40 and 67 percent of Mali's export income during the six-year period from 1998-2003. The contribution of gold exports increased from 1999-2001 and fell a little from 2001-2003, yet still accounted, in 2003, for more than half of the export revenue [23]. Senegal has a population of 12.853 million (July 2008) housed in a space of 196,190 square kilometers [24]. Gold is one of Senegal's main exports account for $13 \%$ of export revenue. Reserves of gold in Senegal are estimated at 1.18 billion US dollars.

\subsection{Study Design}

A case study design was used in this paper. It was based on a wide range of sources to enlighten how regional differences in current forms of local or artisanal gold mining have evolved, as a result of 1) local practices of gold mining, social hierarchies and the allocation of land; 2) colonial administrative and technological interventions, and; 3) geological and geographical context in which people live and work. This approach also facilitated the assessment of the nature of ASM from the perspective of the actors, and addressed why regulation of mercury use in the countries of interest has been an enduring issue for gold mining communities and for policy makers.

\subsection{Focus Group Discussions and Interviews}

The fieldwork in the five countries was conducted between June and December 2011. In each country, the fieldwork was conducted in two phases, in June-September and October-December 2011. The first phase sought to elicit an impression of conditions in the mining areas, an overview of stakeholders, and necessary contacts. In the second and main phase of the fieldwork, interviews were conducted in the mining communities with representatives of the local management of the mining groups, local government authorities, civil society and traditional leaders. Fieldwork was carried out in the Atakora region of northern Benin, and in the Banfora region in the southwestern Comoe Province of Burkina Faso. In Ghana, fieldwork was conducted in Tarkwa, southwestern Ghana, and in Obuasi in the Ashanti region. Baroya, Tabakoto and Sensoko in the Kayes region of Western Mali were included in this study. In Senegal, fieldwork was conducted in the Kédougou Prefecture located in the southeastern corner of Tambacounda, bordered by Guinea and Mali about 
$700 \mathrm{~km}$ from Dakar. Sixteen interviews were conducted in each of the 5 countries. Each of the 80 interviews ranged from 20 minutes to 2.5 hours, with most interviews approximately one hour long. A total of 160 Focus Group Discussions were conducted in the five countries, and of these, 71 were with women, and 89 were with men. Some civil society representatives were interviewed in the capital of each of the 5 countries. While the primary form of data used in this study was interviews, personal observations and documentary analysis were also integral to the overall results and conclusions. Three broad stakeholder groups whose perspectives were deemed important to this study were identified and selected: miners (included those working in formal and informal mining sectors; leaders of small miner organizations - at national, regional, and local level), government (e.g., members of the Ministry of Land and Natural Resources at national and regional levels, local municipal government officials), and civil society (including environmental consultants, NGO personnel involved in the mining sector, and non-mining members of the local communities). There was some overlap between the groups.

\subsection{Documentary Analysis}

Documentary analysis or desk reviews of literature pertaining to published mining permits, national laws and regulations, as well as documents produced by support and mining organisations were carried out prior to fieldwork. Consultation regarding unpublished reports from government ministries (MT, WRC, FC, MC, MLNR, and MLGRD) and local NGOs was done in the course of fieldwork. Informal discussions with staff in stakeholder organisations on the social and environmental impacts of small-scale mining, covering sources of conflicts, problems and risks to the sustainability of their activities were held as part of fieldwork.

\subsection{Data Processing and Analysis}

Using NVIVO 9, all interviews were coded to identify comments related to a list of important themes created from the literature (stakeholder characteristics, nature of ASM, major barriers to cleaner production, policy failure at regulating mercury use) and research goals (use of $\mathrm{Hg}$ in processing, responsibilities, leadership). These themes were assigned preliminary codes and then were later refined throughout the analysis from emergent data. Sub-categories were also assigned to certain categories to separate different responses such as the reasons assigned for policy failure by different stakeholder groups. Respondents were provided code numbers in order to maintain confidentiality. Those participants who were interviewed formally were numbered 1 through 70 , while participants who were interviewed informally were numbered 71 to 80 . 


\subsection{Stakeholder Analysis}

Stakeholder Analysis is recognized as a potent tool for analyzing and assisting the formulation of environmental policy [25]. Since ASM intervention strategies or policies will not affect different groups in society uniformly, it is imperative to assess the impact and consequences of ASM policy on different groups in society. This underscores the significance of stakeholder analysis [26]. There are various ways of mapping the interests, importance and influence of stakeholders. Within the context of this paper stakeholders were analyzed based on the classification scheme proposed by the International Centre for development-oriented Research in Agriculture [27], as shown in Table 1. Stakeholders were also analysed using the matrix of local influence and importance as proposed by [26], and shown in Figure 2.

\section{Results and Discussion}

\subsection{Scope of ASM activities in the Selected West African Countries}

The results show that artisanal gold miners are located in all auriferous areas in each of the selected countries, in the following areas: (1) concessional areas, (2) old surveyed areas, (3) in the fields of local communities (4) farms, (5) conservation areas, (6) urban and (7) other areas not designated for agricultural or farming activities, forestry, mining, conservation or recreation (public areas). This reflects the pervasive nature of ASM across spatial scales in the countries of interest.

\subsection{Stakeholder Analysis}

Table 1. Fundamental Interests of stakeholders around the artisanal gold mining issue

\begin{tabular}{|c|c|c|c|}
\hline Stakeholder & Characteristics & Resource Use & Interest \\
\hline $\begin{array}{l}\text { Artisanal gold } \\
\text { miners }\end{array}$ & $\begin{array}{l}\text { Primary but } \\
\text { passive }\end{array}$ & $\begin{array}{l}\text { Disposal of } \\
\text { untreated mining } \\
\text { wastewater into } \\
\text { surface water, } \\
\text { water withdrawal } \\
\text { \& forest clearing }\end{array}$ & $\begin{array}{l}\text { Economic benefits; do not pay for } \\
\text { environmental management and remediation } \\
\text { services; periodic use of concessions of TNCs }\end{array}$ \\
\hline $\begin{array}{l}\text { Farmers, timber- } \\
\text { and other land users }\end{array}$ & $\begin{array}{l}\text { Primary but } \\
\text { passive }\end{array}$ & $\begin{array}{l}\text { Use of land for } \\
\text { agriculture \& } \\
\text { abstraction of } \\
\text { timber and non- } \\
\text { timber forest } \\
\text { products }\end{array}$ & $\begin{array}{l}\text { Economic benefits from continued farming } \\
\text { and lumbering; land and forest tenure }\end{array}$ \\
\hline $\begin{array}{l}\text { Transnational } \\
\text { Companies (TNCs) }\end{array}$ & Primary but active & $\begin{array}{l}\text { Disposal of treated } \\
\text { mining wastewater } \\
\text { into surface water, } \\
\text { water withdrawal } \\
\text { \& forest clearing, }\end{array}$ & $\begin{array}{l}\text { Economic benefits, corporate social } \\
\text { responsibility }\end{array}$ \\
\hline
\end{tabular}




\begin{tabular}{|c|c|c|c|}
\hline & & $\begin{array}{l}\text { destruction of } \\
\text { farms }\end{array}$ & \\
\hline $\begin{array}{l}\text { Ghana Chamber of } \\
\text { Mines (GCM) }\end{array}$ & Primary but active & - & $\begin{array}{l}\text { Economic benefits, corporate social } \\
\text { responsibility, welfare of TNCs }\end{array}$ \\
\hline $\begin{array}{l}\text { Local Government } \\
\text { Authority }\end{array}$ & $\begin{array}{l}\text { Key, secondary } \\
\text { and active }\end{array}$ & - & $\begin{array}{l}\text { Resource Governance \& Ecological health of } \\
\text { the water bodies, enactment and } \\
\text { enforcement of by-laws }\end{array}$ \\
\hline $\begin{array}{l}\text { Ghana } \\
\text { Environmental } \\
\text { Protection Agency } \\
\text { (GEPA) }\end{array}$ & $\begin{array}{l}\text { Key, secondary } \\
\text { and active }\end{array}$ & - & $\begin{array}{l}\text { Ecological/environmental health of the lagoon; } \\
\text { enforcement of gold mining regulation and } \\
\text { laws }\end{array}$ \\
\hline $\begin{array}{l}\text { Traditional Rulers } \\
\text { and Royal Stools }\end{array}$ & $\begin{array}{l}\text { Key, secondary } \\
\text { and active }\end{array}$ & $\begin{array}{l}\text { Custodians \& } \\
\text { Cultural use of the } \\
\text { land }\end{array}$ & $\begin{array}{l}\text { Sustenance of the cultural practice, history } \\
\text { and beliefs associated with the land and gold } \\
\text { resources }\end{array}$ \\
\hline $\begin{array}{l}\text { Civil Society (Local } \\
\text { \& International } \\
\text { NGOs) }\end{array}$ & $\begin{array}{l}\text { Key and } \\
\text { secondary }\end{array}$ & - & $\begin{array}{l}\text { The ecological/environmental restoration of } \\
\text { water bodies, livelihoods, economic, social \& } \\
\text { political empowerment of gold mining } \\
\text { communities }\end{array}$ \\
\hline $\begin{array}{l}\text { Ministry of Tourism } \\
(\mathrm{MT})\end{array}$ & Key but primary & $\begin{array}{l}\text { Development of } \\
\text { forest tourism }\end{array}$ & $\begin{array}{l}\text { Business/economic benefits, maintenance of } \\
\text { the environmental/landscape aesthetics of the } \\
\text { forest ecological zones }\end{array}$ \\
\hline $\begin{array}{l}\text { Ministry of Local } \\
\text { Government \& } \\
\text { Rural Development } \\
\text { (MLGRD) }\end{array}$ & $\begin{array}{l}\text { Key, secondary } \\
\text { and active }\end{array}$ & - & $\begin{array}{l}\text { Implementation and supervision of } \\
\text { decentralization of resource use and } \\
\text { governance }\end{array}$ \\
\hline $\begin{array}{l}\text { Ministry of Water } \\
\text { Resources, Works } \\
\text { \&Housing } \\
(\text { MWRWH) }\end{array}$ & $\begin{array}{l}\text { Key, secondary } \\
\text { and active }\end{array}$ & - & $\begin{array}{l}\text { Formulation and co-ordination of policies and } \\
\text { programmes for Water Supply, Sanitation and } \\
\text { Hydrology infrastructure. }\end{array}$ \\
\hline $\begin{array}{l}\text { Ministry of Lands \& } \\
\text { Natural Resources } \\
\text { (MLNR) }\end{array}$ & $\begin{array}{l}\text { Key, secondary } \\
\text { and active }\end{array}$ & - & $\begin{array}{l}\text { management of Ghana's land, forest, wildlife } \\
\text { and mineral resources }\end{array}$ \\
\hline $\begin{array}{l}\text { World Bank (WB) } \\
\& \text { International } \\
\text { Monetary Fund } \\
\text { (IMF) }\end{array}$ & $\begin{array}{l}\text { Key, secondary } \\
\text { and active }\end{array}$ & & $\begin{array}{l}\text { Funding and facilitation of natural resource \& } \\
\text { environmental governance (NREG) }\end{array}$ \\
\hline $\begin{array}{l}\text { Water Resources } \\
\text { Commission (WRC) } \\
\text { \& Forestry } \\
\text { Commission (FC) }\end{array}$ & $\begin{array}{l}\text { Key, secondary } \\
\text { and active }\end{array}$ & - & $\begin{array}{l}\text { Management of water resources and co- } \\
\text { ordination of water policies; regulation of } \\
\text { utilization of forest and wildlife resources, } \\
\text { coordination of conservation policies }\end{array}$ \\
\hline $\begin{array}{l}\text { Minerals } \\
\text { Commission (MC) }\end{array}$ & $\begin{array}{l}\text { Key, secondary } \\
\text { and active }\end{array}$ & - & $\begin{array}{l}\text { ensures compliance with Ghana's Mining and } \\
\text { Mineral Laws and Regulation }\end{array}$ \\
\hline $\begin{array}{l}\text { Downstream } \\
\text { communities }\end{array}$ & $\begin{array}{l}\text { Primary but } \\
\text { passive }\end{array}$ & $\begin{array}{l}\text { Drinking of surface } \\
\text { water }\end{array}$ & Water quality and health risk concerns \\
\hline
\end{tabular}

Key stakeholders refer to actors who are considered to have significant influence on the success or otherwise of ASM intervention strategies. Primary stakeholders are the intended beneficiaries of the strategies while secondary stakeholders serve as intermediaries during the implementation of the ASM strategies (e.g., introduction of cleaner and alternative gold extraction technology). Active stakeholders are determinants of decision making while passive stakeholders are affected either positively or negatively by the decisions of others. Here, importance reflects groups whose interests and needs the intervention strategy seeks to address while influence reflects the power certain stakeholders wield over the success of the ASM improvement strategies. Table 1 reflects the 
fundamental interest of various actors in the artisanal gold mining issue, and Figure 2 shows the dynamics of power at the local level in terms of the intervention strategies being implemented in gold mining communities.

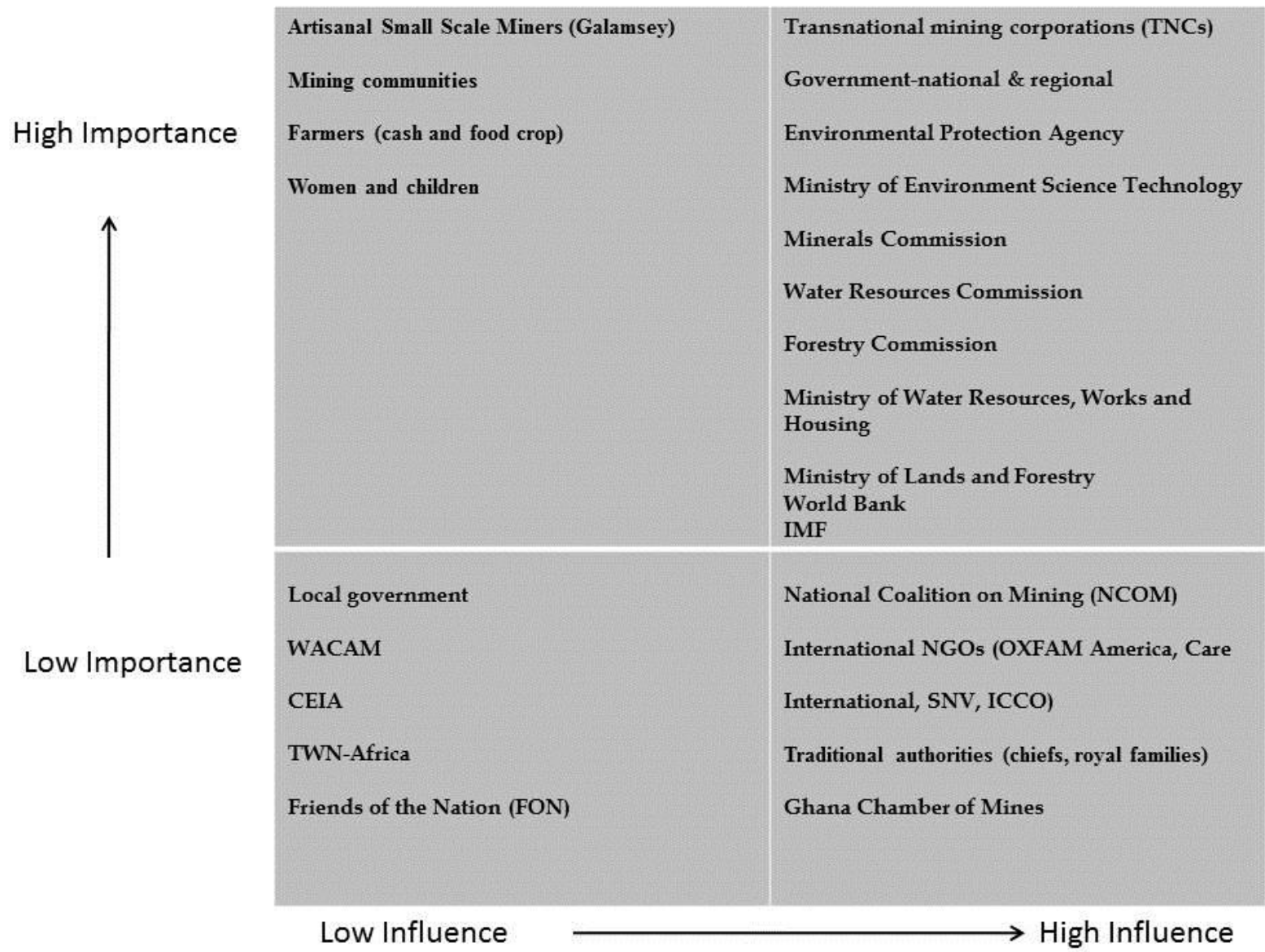

Figure 1. Matrix of stakeholders in ASM and mercury pollution debates in Ghana

\subsection{Nature of Artisanal Gold Mining in the Selected West African Countries}

Although the stakeholder matrix refers specifically to Ghana, it is analogous to the stakeholder types and coalitions that have emerged in the other four countries. For instance, farmers, women, children, local and national governments, state institutions, local and international NGOs are common stakeholders in the five countries. Fundamentally, in all five countries, the problem of ASM-induced mercury pollution was difficult to clearly define by the interviewees. The nature and extent of the problem was contingent on who was asked, that is, different stakeholders had different versions of what was the problem. For instance, in Ghana, various stakeholders (see Figure 2) involved in artisanal gold mining and mercury pollution gave conflicting accounts and conceptions 
of the problem. Artisanal gold miners, broadly, viewed the problem of mercury pollution as derivative of government failure to integrate them into the formal economy. Transnational mining corporations, however, considered the problem to be symptomatic of dysfunctional gold mining policy. Representatives of the Ghana chamber of mines who were interviewed regarded the mercury pollution problem as a product of the incapacity of the Environmental Protection Agency to enforce mining regulation. On the other hand, NGOs such as WACAM and FON contended that the fundamental cause of mercury pollution was alienation of indigenous populations from communal lands and from their original predominantly agricultural livelihoods. This study shows that similar narratives and counter-narratives have appeared within the other West African countries. For instance, this was evident in the Banfora region in the southwestern Comoe Province of Burkina Faso, and in Baroya, Tabakoto and Sensoko in the Kayes region of Western Mali as well as in Worognan in the Sikasso region of Southern Mali. Likewise, the Atakora region of northern Benin has witnessed such debates. The disagreement among ASM stakeholders, thus, reflects the different emphasis they place on the various causal factors. Each of these narratives tends to define itself in contradistinction to the other stories and therefore proposes a different policy solution. As observed in this study and on the basis of the stakeholder perspectives, each version of this policy problem has an element of truth-no one version was complete or verifiably right or wrong (Table 2). The debate has been simplified into competing 'stories' and narratives, which emphasize different aspects of the mercury pollution issue.

Secondly, the ASM and mercury pollution problem has many interdependencies and is multi-causal. There are internally conflicting goals or objectives within the broader mercury pollution problem in the five countries, as shown in Table 2. In dealing with illicit ASM, for example, there is tension between the goal of minimising risk to existing artisanal miners who use mercury in gold extraction via measures such as the provision of safe mining technologies, and the goal of sending a clear message that illicit ASM is illegal. In Ghana, historical antecedents particularly the criminalization of artisanal mining by pre- and post-independence governments alienated this group of miners [28]. In this context, some artisanal miners have claimed they failed to heed the call by government to register and legalize their operations for the reason that they had become accustomed to operating under cover over the years and were uncertain of the prospects and benefits of legalization. Still, many of them remain unregulated so their activities cannot be easily monitored for environmental compliance. Consequently, the problem of mercury pollution will, invariably, be exacerbated. This is unsustainable. Similar miner experiences have been observed in the Tambacounda region of Senegal (an area, which holds the Sabodala Deposit; one of the largest gold deposits in West 
Africa); likewise in the north-west of Benin, in the Atakora Mountains, south of the district capital Natitingou and along the Perma River (in the vicinity of the villages of Kwatena and Tchantangou) [6].

Table 2. Properties of wicked problems and relationship to ASM and mercury pollution in West Africa

\begin{tabular}{|c|c|}
\hline Rittel and Webber & ASM in West Africa \\
\hline There is no definitive formulation of a wicked problem & $\begin{array}{l}\text { Disparate knowledge and opinions on whether } \\
\text { observed water quality patterns and diseases in host } \\
\text { communities are mercury-induced or constitutive of the } \\
\text { natural cycle, for example, significant knowledge exist in } \\
\text { formal institutions (government agencies, NGOs, and } \\
\text { research institutes) and educated residents about } \\
\text { drivers of mercury pollution and human health nexus. } \\
\text { Most laymen and residents in mining communities are } \\
\text { ignorant of drivers of human health effects of mercury } \\
\text { pollution or perceive it as a low risk issue } \\
\text { ii. As a result of differential experiences, perceptions } \\
\text { and political interests of these multiple publics, gold } \\
\text { mining policies, institutions, and infrastructure to adapt } \\
\text { to changing water environment and landscape seem to } \\
\text { be aiming at a moving target }\end{array}$ \\
\hline Wicked problems have no stopping rule & $\begin{array}{l}\text { Mercury pollution and its impacts are progressively } \\
\text { getting worse while uncertainty remains about how long } \\
\text { it will linger on, for example, past surface water quality } \\
\text { records, and future projections point to progressive } \\
\text { deterioration with continuous scarcity and poor quality } \\
\text { of freshwater resources in mining communities } \\
\text { ii. Ominous implications for residents in mining } \\
\text { communities because their capacity to adapt is } \\
\text { threatened by a combination of poverty, disregard for } \\
\text { traditional norms, poor education and knowledge flow, } \\
\text { and dependence on corporate social responsibility, } \\
\text { mainly from TNCs }\end{array}$ \\
\hline $\begin{array}{l}\text { Solutions to wicked problems are not true or false but } \\
\text { good or bad }\end{array}$ & $\begin{array}{l}\text { Although the EPA, WRC, MC, FC, among other public } \\
\text { agencies, are mandated by law, their ability to } \\
\text { determine the correctness of any punitive decision to } \\
\text { implement against artisanal miners and TNCs when in } \\
\text { breach of the mining law undergoes critical scrutiny or } \\
\text { challenge by numerous stakeholder agencies such as } \\
\text { civil society interests involved in the environment and }\end{array}$ \\
\hline
\end{tabular}


There is no immediate and no ultimate test of a solution to a wicked problem water sector and the Chamber of Mines

Because the major stakeholders operate at the national scale, it is impossible for regional and local actors to determine when desired results of a proposed intervention to adapt water systems to mercury pollution has been achieved, especially taking into account the inability of any system to fully account for all unintended outcomes prior to or post intervention

Every solution to a wicked problem is a "one-shot operation" because there is no opportunity to learn by trial and error; every attempt counts significantly

ASM activities create water shortages through drying up of local streams and perennial rivers and disturb water quality. Conventional solutions have resorted to restricting use of such water resources. Yet, these solutions have brought irreversible hardships to communities that depend on these rivers for their livelihoods and water needs

Wicked problems do not have an enumerable (or exhaustively describable) set of potential solutions, and there is no well described set of permissible operations that may be incorporated into the plan

Every wicked problem is essentially unique

ASM-related water quality resolutions are politically shaped by varying experiences, ideologies, and power of stakeholders from international to local levels. Ghana has no agreement criteria for judging successfully completed water quality restoration programs carried out by artisanal miners or TNCs; uncertainty is prevalent

By scale and intensity, ASM-induced mercury toxicity and human health is one of a kind, thus insufficient or inappropriate solutions emanating from knowledge gained from traditional and formal institutional arrangements over the years fail to account for complexity. The situation is exacerbated by disjointed collaboration among stakeholder institutions
Every wicked problem can be considered to be a symptom of another problem

The impacts of mercury load on water quality and quantity reveal growing concerns about their interconnections with other intractable national and global problems, for example, an unjust global geopolitics, deteriorating social and ecological systems, poverty, misfit/incapable institutions and resource governance system, etc. Therefore, singular action on mercury pollution without attention to related problems will be ineffective.

The existence of a discrepancy representing a wicked problem can be explained in numerous ways. The choice of explanation determines the nature of the
Traditional authority and informal knowledge are often sidelined by experts from state and formal agencies; thus, indigenous knowledge on day to day water quality 


\begin{tabular}{l|l}
\hline problem's resolution & monitoring and remediation does not feed into policy \\
\hline $\begin{array}{l}\text { The planner has no right to be wrong (Planners are } \\
\text { liable for the consequences of the actions they }\end{array}$ & $\begin{array}{l}\text { The precautionary principle is implied here, a key } \\
\text { element of Ghana Water Policy. However, current } \\
\text { generate) }\end{array}$ \\
$\begin{array}{l}\text { Gonaian practice places no liability on planners and } \\
\text { diligence, probably justifiably so because learning from } \\
\text { experience and even mistakes (adaptive) is fundamental } \\
\text { to building capacities against latent uncertainties of } \\
\text { mercury toxicity, bioaccumulation in the food chain and } \\
\text { human health outcomes. }\end{array}$
\end{tabular}

Note: TNCs= transnational corporations; $M C=$ Mineral Commission; EPA = Environment Protection Agency; $\mathrm{WRC}=$ Water Resources Commission; FC = Forestry Commission

Third, attempts to address wicked problems often lead to unforeseen consequences. This point is illustrated with an example from Ghana. During the colonial era, the preference of Ghanaians to work in their own mines rather than work for Europeans encouraged the Colonial Office to pass the Mercury Ordinance of 1932, making it illegal for Ghanaians to use mercury for mining. This marked the beginning of the criminalization of indigenous, small-scale gold mining and the edging out of Ghanaian gold producers, until 1989 when the Small-scale Mining Law was enacted to give legal status to the sector again [28]. Potentially, the law was environmentally friendly as it aimed at reducing mercury emissions to the atmosphere. However, in retrospect, the ordinance rather worsened the magnitude and frequency of mercury emissions. This is because the ordinance compelled indigenous artisanal miners, all of whom were users of mercury, to go into hiding for over 60 years. Their mercury use and unregulated activities were carried out in secrecy leading to widespread contamination of surface water bodies. Consequently, the persistence of mercury use in ASM is inextricably linked to this ordinance.

Next, ASM and mercury pollution is unstable and appears to defy regulation (Table 2). In southwestern Ghana, particularly, Obuasi (Ashanti region) and Tarkwa (Western region) as in Burkina Faso, especially, Guéguéré (Ioba Province), Tiba District (Boulgou Province), and Nagrigré (Zoundweogo province), the activities of artisanal miners have resisted regulation. The ASM and mercury pollution problem and the constraints or evidence involved in understanding the problem (e.g. legislation, scientific evidence, resources, political alliances), are evolving at the same time that policy makers are trying to address the policy problem. Thus, policy makers have to focus on a moving target (Table 2). The number of stakeholders is evolving with time as are the central policy issues. In Figure 2, for instance, some of the stakeholders (e.g. CEIA and FON) were unknown 10 to 15 years ago. Their emergence indicates that the stakeholders of ASM are in dynamic flux. 
Furthermore, the social complexity of the ASM and mercury pollution issue can be observed in the multiplicity of stakeholders and the spatial scale at which they operate. For example, in Figure 1, there are linkages and feedbacks between stakeholders at the individual, household, community, and district, regional, national, and international levels. Actions of stakeholders at one level may hold implications for stakeholders at other levels. Therefore, solutions to ASM and mercury pollution should encourage coordinated action by a range of stakeholders, including organisations (government agencies at the national, regional and local levels), non-profit organisations, private businesses and individuals.

Also, it is obvious that the problem of mercury pollution does not sit conveniently within the responsibility of any one organization; and is characterized by chronic policy failure. It has been asserted, for example, that the failure of policies designed to regulate ASM in Ghana may be partly responsible for an apparent increase in mercury-induced surface water pollution in mining areas over the past 80 years [29]. Traditional bureaucracy, divided into vertical strata, in which most of the authority for resolving problems rests at the top of the organisation, is not well-adapted to support the kinds of process necessary for addressing the complexity and ambiguity of ASM and mercury pollution. Usually, bureaucracies tend to be risk averse, and are intolerant of messy processes [14]. They excel at managing issues with clear boundaries rather than ambiguous, complex issues that may require experimental and innovative approaches. Engagement is most important when the active participation and cooperation of citizens is required as part of the solution. Because mercury pollution is imperfectly understood, it is important that it is widely discussed by all relevant stakeholders in order to ensure a full understanding of their complexity [14].

Usually, part of the solution to wicked problems involves changing the behaviour of groups of citizens or all citizens [14]. The colonial policy to ban ASM did not necessarily limit the use of mercury neither did the lifting of this ban in 1989 and subsequent partial regularization of ASM activities reduce mercury pollution. Resolution of mercury pollution from ASM activities requires changes to the way people behave; these changes cannot readily be imposed on people. Behaviours are more conducive to change if issues are widely understood, discussed and owned by the people (artisanal miners) whose behaviour is being targeted for change.

Other key ingredients in solving or at least managing this complex policy problem include successfully working across both internal and external organizational boundaries and engaging 
citizens and stakeholders in policy making and implementation [17]. The mercury pollution problem requires innovative, comprehensive solutions that can be modified in the light of experience and on-the-ground feedback. All of the above can pose challenges to traditional approaches to policy making and programme implementation. Lately, several cross-spatial initiatives that are responsive to some of the issues highlighted above have been initiated in the five countries. For instance, in Burkina Faso, Mali and Senegal, the United Nations Industrial Development Organization (UNIDO), the Global Environment Facility (GEF), and the United States Department of State have commenced a regional program that builds local capacities to address the growing issues surrounding ASM including the use of mercury and cyanide, regularization of the informal economy, health and safety, and supply chain management. The program includes training and education programs using a variety of approaches including print media, demonstrations, social media, and cell phones. In Ghana, the program is also working with the University of Mines at Tarkwa (UMaT) to develop, improve, and introduce direct smelting technology to groups of miners who use mercury to recover gold. Over the past five years, UMaT has successfully developed a direct smelting kit, which has been provided to miners at subsidized rates. This initiative has demonstrated that purifying gold without the use of mercury is possible in this context. The kit consists of an efficient furnace, a few common compounds, and some other tools which enable gold concentrates to be directly smelted, thereby avoiding the mercury amalgamation step.

\subsection{Characterising Artisanal Gold Mining: A Conundrum?}

Hitherto, a shortcoming of much analysis of the artisanal gold mining phenomenon has been the failure to make a clear distinction between the size of mining (artisanal, small, medium or largescale) and its mode of operation (illegal, informal or formal). This has often resulted in misconceptions about what the precise characteristics of ASM operations are. For instance, the term has different meanings in the 5 different countries studied and beyond. For their own purposes, countries have devised unique definitions of "artisanal" and/or "small-scale mining", according to a variety of criteria such as the following: Level of mechanisation (e.g. as in Burkina Faso and Ghana); size of concession (e.g. as in Ghana); depth of working (e.g. as in Senegal); capital investment (e.g. as in South Africa); level of employment (e.g. as in Chile); and production levels (e.g. as in Senegal). Certain countries have made a distinction between small-scale and artisanal mining in legislation; in such cases, the former is associated with illegal activities and minimal mechanisation, and the latter, with semi-mechanisation and organisation [30, 31]. Notwithstanding this, the ASM issue has been framed from several perspectives as shown below. 


\subsection{Multiple framings of ASM by various actors in West Africa}

It was observed that ASM was framed severally by various stakeholders in the 5 countries. Interestingly, allied stakeholder groups framed the issue in an identical manner irrespective of the country concerned. For instance, in all five countries, ASM was framed as a human rights issue usually by international NGOs. In Mali, for instance, children between the ages of 6 and 17 indicated they dug pits, worked underground in unstable mines, carried and crushed heavy ore, and used toxic mercury to extract gold in artisanal gold mines in Kéniéba and Kolondiéba. ASM was framed as an environmental issue in all five countries. In this context, the bioaccumulation of methylmercury in the food and subsequent ingestion by residents of downstream communities as they eat contaminated fish was a popular narrative by government. Civil society stakeholders also framed ASM as a health issue and made particular reference to mercury toxicity and its association with permanent overt brain damage, seizures, vision and hearing loss, delayed childhood development, language disorders, deficits in fine motor functions and memory issues [28]. Interestingly, in this study, it was found that seldom did artisanal miners frame ASM as a health issue.

The local NGOs in the five countries tended to frame ASM as a political issue. Political perceptions and attitudes towards the ASM sector are central to progressive policy processes. To a large extent, however the industry has always been viewed politically as a marginal sector because of its geographic remoteness, rudimentary nature, association with the higher profile TNCs, and Government and public perceptions of its significance in relation to other sectors such as agriculture. Although contemporary scholarship indicates the increasing integration of ASM in the national economies of the five countries, this study found the rate and extent of integration were still low. The relationship between TNCs and ASM is complex and reflected in the political attention afforded to the two sectors. The latter is often seen as inextricably linked to the former in a variety of ways (e.g. prospectors, existing land users, trespassers, neighbours etc.). There are some examples of mutually beneficial interaction between the two groups [32, 33] but in the majority of cases, relationships are strained, with conflicts resulting from dispute over control and access land and minerals [34]. This tension is exacerbated by the infiltration of foreigners who by law are not permitted to mine on a small scale into the ASM sector. In Ghana, for instance, the influx of the Chinese into the sector has generated a lot of tension and threatens to undermine the political and economic ties between Ghana and China [35].

ASM was framed as an institutional and legal issue especially by the representatives of government and international NGOs though some artisanal miners also alluded to it. Issues that emerged within 
this framing include limited legalization and provision of security tenure to small scale mining communities; lack of a regional certification mechanism; limited harmonisation of national legislation; absence of regional database on mineral flows; limited or no formalisation of the artisanal gold mining sector; and limited involvement in the Extractive Industry Transparency Initiative (EITI).

ASM was delineated as a socio-economic issue mostly by artisanal miners. In this vein, the artisanal miners were unequivocal that it was a question of survival, poverty alleviation and livelihood. For instance, some artisanal miners in Ghana and Senegal quipped

"...should we wait for all the gold to disappear before claiming what rightfully belongs to us? We have to survive on our heritage..."

Mostly, the World Bank and the IMF viewed the ASM issue in West Africa as a technological issue. They argued that there were a number of cleaner technology alternatives to current methods of mercury amalgamation. Education was identified as a barrier to technology adoption by small scale miners. It has been suggested that the use of retorts during the mercury burn-off stage is a simple and cost-effective way to decrease the occupational exposure to mercury and minimize its release into the environment. Based on this technological worldview the two organisations had sponsored education and cleaner technology programs in the countries studied.

The framing of ASM as a man-made hazard provides an interesting view of the issue. This is because the artisanal miners involved in it viewed the activity as a low risk issue and were relatively unconcerned about the hazard it posed to them. However, interviewees in government agencies rather considered it a man-made hazard. In fact, one of representatives from a government agency in Ghana referred to ASM as a "latent time-bomb". In Ghana alone, collapses of more than 200 mine pits have been reported by the media in the last 10 years. Cumulatively, more than 2000 people were alleged to have died and several thousands have either been trapped or severely injured in these incidents. Mine pit collapses have also been reported in the Sudan, Tanzania, Sierra Leone and the Democratic Republic of Congo in which several hundreds of artisanal miners died. This situation is even more critical when viewed against the background that for every reported pit collapse, about three other pit collapses goes unreported.

\section{Conclusion}

In this paper, artisanal gold mining and its associated mercury pollution was characterised as a wicked environmental problem for public policy making. It is concluded that the social complexity 
of the ASM and mercury pollution problem, rather than its technical complexity, overwhelms most current problem-solving and project management approaches. The colonial policy to ban ASM did not necessarily limit the use of mercury neither did the lifting of this ban in 1989 and subsequent partial regularization of ASM activities reduce mercury pollution. Although tackling the ASM and mercury pollution problem is an evolving art, it however requires holistic, not partial or linear thinking, innovative and flexible approaches, the ability to work across agency boundaries, increasing understanding and stimulating a debate on the application of the accountability framework, effectively engaging stakeholders and citizens in understanding the problem and in identifying possible solutions, a better understanding of behavioural change by policy makers, and tolerating uncertainty and accepting the need for a long-term focus. These approaches are not intended as a panacea but stand a greater chance of succeeding where traditional approaches have practically failed. It is in this way that we stand a chance of nearing sustainability.

\section{Acknowledgments}

I wish to express my profoundest gratitude to the focus group discussants and interviewees for willingly participating in this study.

\section{Conflict of Interest}

The author declares no conflict of interest.

\section{References}

1. United Nations Environment Programme-UNEP (2012). Reducing Mercury in Artisanal and SmallScale Gold Mining (ASGM): A practical Guide. UNEP: Nairobi, Kenya, 2012; pp. 20-35.

2. Schmeltz, D.; Evers, D.C.; Driscoll, C.T.; Artz, R.; Cohen, M.; Gay, D.; Haeuber, R.; Krabbenhoft, D.P.; Mason, R.; Morris, K.; Wiener, J.G. MercNet: a national monitoring network to assess responses to changing mercury emissions in the United States. Ecotoxicology 2011, 20 (7), 1713-1725.

3. Veiga, M.M.; Baker, R. Protocols for Environmental and Health Assessment of Mercury Released by Artisanal and Small Scale Miners. Report to the Global Mercury Project: Removal of Barriers to Introduction of Cleaner Artisanal Gold Mining and Extraction Technologies, GEF/UNDP/UNIDO, 2004; 68-74.

4. Bose-O'Reilly, S.; McCarty, K.M.; Steckling, N.; Lettmeier, B. Mercury Exposure and Children's Health. Current Problems in Pediatric and Adolescent Health Care 2010a, 40, 186-215.

5. Spiegel, S. J. Occupational Health, Mercury Exposure, and Environmental Justice: Learning from Experiences in Tanzania. American Journal of Public Health 2009, 99 (3), 550-558. 
6. Gratz, T. Moralities, risk and rules in West African artisanal gold mining communities: A case study of Northern Benin. Resources Policy 2009, 34 (1-2), 12-17.

7. Jaques, E.; Zida, B.; Billa, M.; Greffié, C.; Thomassin, J.F. Artisanal and small-scale gold mines in Burkina Faso: today and tomorrow. In: Small-scale mining, rural subsistence and poverty and WestAfrica, Hilson, G.M., ed.; Practical Action Publishing: Rugby, UK, 2008; 354 p.

8. Donkor, A. K.; Bonzongo, J. C.; Nartey, V. K.; Adotey, D. K. Mercury in different environmental compartments of the pra river basin, Ghana. Science of the Total Environment 2006, 368(1), 164-176.

9. Obiri, S., Dodoo, D.K., Essumang, D.K., Armah, F.A. Cancer and non-cancer risk assessment from exposure to arsenic, cadmium and copper by resident adults and children in the Obuasi Municipality, Ghana. International Journal of Human and Ecological Risk Assessment 2010, 16 (3), 651-665.

10. Bose-O'Reilly, S.; McCarty, K.M.; Steckling, N.; Lettmeier, B. Mercury Exposure and Children's Health. World's Worst Pollution Problems Report 2010: Top Six Toxic Threats. Blacksmith Institute/Green Cross, Switzerland. Blacksmith Institute: New York, USA ; pp. 33-38, 188-189.

11. Rittel, H. W. J.; Webber, M. M. Dilemmas in a general theory of planning. Policy Sciences 1973, 4(2), 55-169.

12. Ackoff, R. Re-defining the Future. Wiley: London, UK, 1974.

13. Mackenzie, A.; Pidd, M.; Rooksby, J.; Sommerville, I.; Warren, I.; Westcombe, M. (2006). Wisdom, decision support and paradigms of decision making. European Journal of Operational Research 2006, 170(1), 156-171.

14. Ritchey, T. Wicked Problems - Social Messes: Decision support Modelling with Morphological Analysis. Springer: Berlin, Germany; 2011.

15. Ney, S. Resolving messy policy problems: handling conflict in environmental, transport, health and ageing policy. Earthscan, UK, 2009.

16. Roberts, N. Public Deliberation in an Age of Direct Citizen Participation. The American Review of Public Administration 2004, 34(4), 315- 346.

17. Heifetz, R.A. Leadership without answers. Cambridge, Mass.: Belknap Press of Harvard University Press, 1994.

18. Schon, D. A. Frame Reflection: Toward the Resolution of intractable policy controversies. Basic Books: USA, 1999.

19. Weber, E.P.; Khademian, A.M. Wicked Problems, Knowledge Challenges, and Collaborative Capacity Builders in Network Settings. Public Administration Review 2008, 68(2), 334-339.

20. United Nations, Department of Economic and Social Affairs (UNDESA), Population Division. World Population Prospects: The 2012 Revision, Highlights and Advance Tables. ESA/P/WP.228, 2013. 
21. National Institute of Statistics and Demography (INSD). Population by region and gender from 1997 to 2012. National Institute of Statistics and Demography. INSD Press: Ouagadougou, Burkina Faso, 2013.

22. Ghana Statistical Service. 2010 Population and Housing Census (PHC) Final Results. Ghana Statistical Service: Accra, Ghana, 2012.

23. National Institute of Statistics (INS). 4th Census of Population and Housing of Mali (RGPH) final results part 1: Demographic Series. National Institute of Statistics: Bamako, Mali, 2011.

24. National Agency of Statistics and Demography. Key indicators of Senegal. National Agency of Statistics and Demography. ANSD: Dakar, Senegal, 2013.

25. Edelenbos, J.; Klijn, E-H. Managing Stakeholder Involvement in Decision Making: A Comparative Analysis of Six Interactive Processes in the Netherlands. Journal of Public Administration Research and Theory 2006, 16(3), 417-446.

26. Grimble, R.; Wellard, K. Stakeholder methodologies in natural resource management: a review of principles, contexts, experiences and opportunities. Agricultural Systems 1997, 55(2), 173-193.

27. International Centre for development oriented Research in Agiculture (ICRA) (2005). ICRA Stakeholder Module. Retrieved on December 20, 2007 from ICRA STAKEHOLDER ANALYSIS: http://www.icra-edu.org/objects/anglolearn/Stakeholders-Key_Concepts.pdf

28. Armah, F.A.; Luginaah, I.; Taabazuing, J.; Odoi, J.O. Artisanal Gold Mining and Surface Water Pollution in Ghana: Have the Foreign Invaders come to Stay? Environmental Justice 2013a, 6(3), 94102.

29. Armah, F.A.; Obiri, S.; Yawson, D.O.; Afrifa, EK.A; Yengoh, G.T.; Alkan Olsson, J.; Odoi, J.O. 2011. Assessment of legal framework for corporate environmental behaviour and perceptions of residents in mining communities in Ghana. Journal of Environmental Planning and Management 2011, 54(2), 193-209.

30. D'Souza, K. Artisanal and small-scale mining in Africa: a reality check, keynote presentation at the Seminar on Artisanal and Small-scale Mining in Africa. Yaoundé, Cameroon, 2002. http://www.un.org/esa/sustdev/tech_coop/documents/seminar_Yaounde/Sessio n1_Souza.pdf

31. Quiroga, E. R. The case of artisanal mining in Bolivia: local participatory development and mining investment opportunities. Natural Resources Forum 2002, 26, 127-139.

32. Davidson, J.; Mendez, M-E. Status report on the process of BPD engagement with Minera Las Cristinas C.A., MINCA, Las Cristinas/BPD Status Report, 2000.

33. Hilson, G. A contextual review of the Ghanaian small-scale mining industry. IIED and WBCSD, 2001.

34. Chachage S.L. The meek shall inherit the earth but not the mining rights: the mining industry and accumulation in Tanzania', in Gibbon, Peter (ed.) Liberalised Development in Tanzania: Studies on accumulation processes and local institutions, Nordiska Afrikainstituter: Uppsala, 1995. 
35. Armah, F.A.; Luginaah, I.N.; Odoi, J.O. Artisanal small-scale gold mining and mercury pollution in Ghana: A critical examination of a messy minerals and gold mining policy debate. Journal of Environmental Studies and Sciences 2013b, DOI: 10.1007/s13412-013-0147-7.

(C) 2013 by the authors; licensee MDPI, Basel, Switzerland. This article is an open access article distributed under the terms and conditions of the Creative Commons Attribution license (http://creativecommons.org/licenses/by/3.0/). 